\title{
Activation of PPAR $\gamma$ in bladder cancer via introduction of the long arm of human chromosome 9
}

\author{
RYUTARO SHIMIZU $^{1,2}$, TAKAHITO OHIRA ${ }^{2,3}$, TAKUKI YAGYU ${ }^{2,4}$, TETSUYA YUMIOKA ${ }^{1}$, \\ NORIYA YAMAGUCHI ${ }^{1}$, HIDETO IWAMOTO ${ }^{1}$, SHUICHI MORIZANE ${ }^{1}$, KATSUYA HIKITA $^{1}$, \\ MASASHI HONDA ${ }^{1}$, ATSUSHI TAKENAKA ${ }^{1}$ and HIROYUKI KUGOH ${ }^{2,3}$ \\ ${ }^{1}$ Division of Urology, Department of Surgery, Tottori University Faculty of Medicine, Yonago, Tottori 683-8504; \\ ${ }^{2}$ Department of Molecular and Cellular Biology, Division of Genome and Cellular Function; \\ ${ }^{3}$ Chromosome Engineering Research Center, Tottori University, Yonago, Tottori 683-8503; \\ ${ }^{4}$ Division of Gastrointestinal and Pediatric Surgery, Department of Surgery, School of Medicine, \\ Faculty of Medicine, Tottori University, Yonago, Tottori 683-8504, Japan
}

Received December 1, 2021; Accepted January 5, 2022

DOI: 10.3892/ol.2022.13212

\begin{abstract}
Bladder cancer is divided into two molecular subtypes, luminal and basal, which form papillary and nodular tumors, respectively, and are identifiable by gene expression profiling. Although loss of heterozygosity (LOH) of the long arm of human chromosome 9 (9q) has been observed in the early development of both types of bladder cancer, the functional significance of $\mathrm{LOH}$ remains to be clarified. The present study introduced human chromosome $9 \mathrm{q}$ into basal bladder cancer cell line, SCaBER, using microcell-mediated chromosome transfer to investigate the effect of $\mathrm{LOH}$ of $9 \mathrm{q}$ on molecular bladder cancer subtypes. These cells demonstrated decreased proliferation and migration capacity compared with parental and control cells. Conversely, transfer of human chromosome $4 \mathrm{did}$ not change the cell phenotype. Expression level of peroxisome proliferator-activated receptor (PPAR) $\gamma$, a marker of luminal type, increased 3.0-4.4 fold in SCaBER cells altered with $9 q$ compared with parental SCaBER cells. Furthermore, the expression levels of tumor suppressor PTEN, which regulates PPAR $\gamma$, also increased in 9q-altered cells. These results suggested that human chromosome $9 \mathrm{q}$ may carry regulatory genes for PPAR $\gamma$ that are involved in the progression of neoplastic transformation of bladder cancer.
\end{abstract}

Correspondence to: Professor Hiroyuki Kugoh, Chromosome Engineering Research Center, Tottori University, 86 Nishicho, Yonago, Tottori 683-8503, Japan

E-mail:kugoh@tottori-u.ac.jp

Key words: long arm of chromosome 9, loss of heterozygosity, bladder cancer, peroxisome proliferator-activated receptor $\gamma$, tumor suppressor gene

\section{Introduction}

Bladder cancer (BCa) is one of the most prevalent types of malignant tumor of the urinary system (1). BCas are classified as superficial papillary or non-papillary carcinoma according to their constitution (2). Papillary carcinoma is usually non-invasive but may develop into non-papillary invasive carcinoma with a high histological grade, with repeated recurrence after treatment. Conversely, non-papillary invasive carcinoma usually has a high histological grade and poor clinical course. Various chromosomal aberrations are involved in the development and progression of these types of cancer. Generally, there are two types of chromosomal aberration: Primary, which is associated with tumor oncogenesis, and secondary, which is associated with tumor progression (3). Using comparative genomic hybridization and loss of heterozygosity (LOH) analysis, aberrations in urothelial carcinoma have been observed on human chromosomes 1p, 9 and 11p, which contain numerous onco- and tumor suppressor genes, such as runt-related transcription factor 3, cyclin-dependent kinase inhibitor 2A and cyclin D1 (4). Advanced BCa is accompanied by aberrations in human chromosomes $2 \mathrm{q}, 5 \mathrm{q}$, and $8 \mathrm{p}$ (5-7). Furthermore, insights in the molecular pathology of $\mathrm{BCa}$ suggest two pathways for the development of $\mathrm{BCa}$ : Luminal and basal subtype (8). The $\mathrm{q}$ arm of chromosome 9 is deleted in both molecular subtypes, suggesting that it may be a primary event in the pathogenesis of $\mathrm{BCa}(9,10)$. Inactivating mutations of tuberous sclerosis 1 , which is a key tumor suppressor gene on $9 \mathrm{q}$, is found in $11-16 \%$ of $\mathrm{BCa}$ cases, regardless of stage $(11,12)$. Mutations in Notch homolog 1 , located on 9q, have also been identified in $18 \%$ of $\mathrm{BCa}(13)$. The aberration rates of these tumor suppressor genes are inconsistent with the degree of $\mathrm{LOH}$ in $\mathrm{BCa}$, suggesting the presence of novel tumor suppressor genes that contribute to cancer development.

To understand the functional significance of the $\mathrm{LOH}$ at the $9 \mathrm{q}$ region in $\mathrm{BCa}$ development, human chromosome $9 \mathrm{q}$ was transferred to a $\mathrm{BCa}$ cell line using microcell-mediated 
chromosome transfer (MMCT) and examined for effects on phenotype.

\section{Materials and methods}

Cell lines and culture. SCaBER and RT4 cells were purchased from the American Type Culture Collection. T24 and 5637 cells were purchased from the RIKEN Cell Bank. Cells were cultured in DMEM (Sigma-Aldrich; Merck KGaA) supplemented with $10 \%$ fetal bovine serum (FBS; HyClone; Cytiva), $100 \mathrm{U} / \mathrm{ml}$ penicillin and $100 \mu \mathrm{g} / \mathrm{ml}$ streptomycin (FUJIFILM Wako Pure Chemical Corporation). Mouse A9 cells containing human chromosome $9 \mathrm{q}$ or 4 , respectively, tagged with neomycin resistance gene (neo) were maintained in DMEM supplemented with 10\% FBS and $800 \mu \mathrm{g} / \mathrm{ml} \mathrm{G418}$ antibiotic (Calbiochem; Merck KGaA) and used as chromosome donors. All cell lines were maintained at $37^{\circ} \mathrm{C}$ in a humidified incubator with $5 \% \mathrm{CO}_{2}$.

MMCT. Chromosome transfer via chromosome engineering was performed as previously described (14). A9(neo9q) or A9(neo4) cells were treated with $0.05 \mu \mathrm{g} / \mathrm{ml}$ colcemid at $37^{\circ} \mathrm{C}$ for $48 \mathrm{~h}$ to induce formation of micronuclei, which were then purified by cytochalasin B $(10 \mu \mathrm{g} / \mathrm{ml})$ digestion and centrifugation at $11,900 \mathrm{x}$ g for $60 \mathrm{~min}$ at $34^{\circ} \mathrm{C}$. The isolated microcells were then resuspended in serum-free DMEM and filtered sequentially through 8,5 and $3 \mu \mathrm{m}$ polycarbonate filters (Whatman plc; Cytiva). The purified microcells were collected by centrifugation at $400 \mathrm{x} \mathrm{g}$ for $15 \mathrm{~min}$ at room temperature (RT) and resuspended in serum-free DMEM containing $50 \mu \mathrm{g} / \mathrm{ml}$ phytohemagglutinin-P (FUJIFILM Wako Pure Chemical Corporation). The microcells were attached to the cell monolayer at $37^{\circ} \mathrm{C}$ for $15 \mathrm{~min}$, fused with recipient cells in $47 \%$ polyethylene glycol solution for $1 \mathrm{~min}$ at RT, followed by washing with serum-free DMEM. Cells then maintained in non-selective medium (DMEM) for $24 \mathrm{~h}$ at $37^{\circ} \mathrm{C}$, trypsinized and divided into six $100 \mathrm{~mm}$ dishes containing selection medium (containing $800 \mu \mathrm{g} / \mathrm{ml} \mathrm{G} 418$ ).

Acquisition of microcellular hybrid clones. The day after microcell fusion, culture medium was changed to selection medium (containing $800 \mu \mathrm{g} / \mathrm{ml} \mathrm{G} 418$ ). One week after fusion, no viable cells were observed. Two weeks after fusion, rapidly proliferating clones were isolated and maintained by serial passaging, as previously described (14).

Genomic PCR analysis. The presence of the 9p24.2-9q34.3 region on human chromosome $9 \mathrm{q}$ contained in A9(neo9) was verified by PCR using 21 specific sequence-tagged site (STS) markers (D9S54, 9p24.2; D9S268, 9p23; D9S285, 9p22.3; D9S165, 9p21.1; D9S200, 9p13.1; SHGC-103793, 9p12; UT801, 9p11.2; SHGC-141463, 9q12; SHGC-146514, 9q13; D9S15, 9q21.12; D9S1122, 9q21.2; D9S153, 9q21.31; D9S777, 9q22.1; D9S318, 9q22.2; D9S287, 9q22.32; D9S277, 9q31.1; D9S177, 9q33.1; D9S290, 9q34.11; D9S66, 9q34.2; and D9S158, 9q34.3). Primer sequences were obtained from the National Center for Biotechnology Information (https://www.ncbi.nlm. nih.gov). PCR was performed with 35 cycles of $30 \mathrm{sec}$ at $94^{\circ} \mathrm{C}$, $30 \mathrm{sec}$ at $58-62^{\circ} \mathrm{C}$ and $30 \mathrm{sec}$ at $72^{\circ} \mathrm{C}$.
RNA isolation and reverse transcription-quantitative PCR. Total RNA was extracted using RNeasy Mini kit (Qiagen $\mathrm{GmbH}$ ) from each cell line and treated with DNase I (FUJIFILM Wako Pure Chemical Corporation). First-strand cDNA was synthesized using M-MLV reverse transcriptase (Invitrogen; Thermo Fisher Scientific, Inc.) with random primers (Invitrogen; Thermo Fisher Scientific, Inc.), 5x First Strand Buffer (Invitrogen; Thermo Fisher Scientific, Inc.) and dNTPs (Applied Biosystems; Thermo Fisher Scientific, Inc.). The temperature protocol was $23^{\circ} \mathrm{C}$ for 12 min for primer annealing, followed by $42^{\circ} \mathrm{C}$ for $50 \mathrm{~min}$ for reverse transcription and then $95^{\circ} \mathrm{C}$ for $5 \mathrm{~min}$ for enzyme inactivation.

The mRNA expression of PPARG (encoding PPAR $\gamma$ ), forkhead box A1 (FOXA1) and GATA3 was analyzed using specific primers as follows: PPARG forward, 5'-GACAGG AAAGACAACAGACAAATC-3' and reverse, 5'-GGGGTG ATGTGTTTGAACTTG-3'; FOXA1 forward, 5'-AGGGCT GGATGGTTGTATTG-3' and reverse, 5'-ACCGGGACG GAGGAGTAG-3' and GATA3 forward, 5'-GCTTCGGAT GCAAGTCCA-3' and reverse, 5'-GCCCCACAGTTCACA CACT-3'. cDNA was amplified using an Applied Biosystems StepOne thermal cycler system and SYBR Green PCR kit (Applied Biosystems; Thermo Fisher Scientific, Inc.). mRNA levels were normalized against GAPDH mRNA (PCR primers: Forward, 5'-AGCCACATCGCTCAGACAC-3' and reverse, 5'-GCCCAATACGACCAAATCC-3') using the $2^{-\Delta \Delta C q}$ method (15). Thermocycling conditions were $10 \mathrm{~min}$ at $95^{\circ} \mathrm{C}$ for denaturation, followed by $15 \mathrm{sec}$ at $95^{\circ} \mathrm{C}$ and $60 \mathrm{sec}$ at $60^{\circ} \mathrm{C}$ for denaturation and annealing/extension for 40 cycles. The experiments were performed in triplicate.

Heatmap of gene expression. The expression levels of PPARG, FOXA1, and GATA3 of RT4, T24, SCaBER, SCaBER\#4 and SCaBER9q were visualized using a freely available web server, Heatmapper (http://www.heatmapper.ca.).

Fluorescence in situ hybridization (FISH). To identify successful transference of chromosome 9q in metaphase spreads, chromosomal FISH was performed using plasmid pSV2neo as a probe. The transferred chromosome 4 was identified using RP11-84C13 BAC DNA as a probe.

The preparation of chromosome slides, probe labeling, hybridization, washing and detection of signals were performed as previously described (16).

Cell proliferation assay. Cell proliferation assay was performed to evaluate the proliferation capability of cells. SCaBER, SCaBER\#4, and SCaBER\#9q cells were seeded at $1.0 \times 10^{5}$ cells in a $6 \mathrm{~cm}$ dish. All cells were cultured in DMEM supplemented with $10 \%$ FBS. Measurements were made using a hemocytometer on days $1,2,3,4$, and 5 after seeding. Cell counting was performed three times.

Migration assay. Wound healing assay was performed to evaluate the migration capability of cells. SCaBER, SCaBER\#4 and SCaBER\#9q cells were grown to $100 \%$ confluence in a $6-\mathrm{cm}$ dish and a scratch was made with 200- $\mu 1$ pipette tips. The cells were washed with PBS and placed in serum-free medium (DMEM). The wound width at 0 and $24 \mathrm{~h}$ was measured and evaluated using a digital 


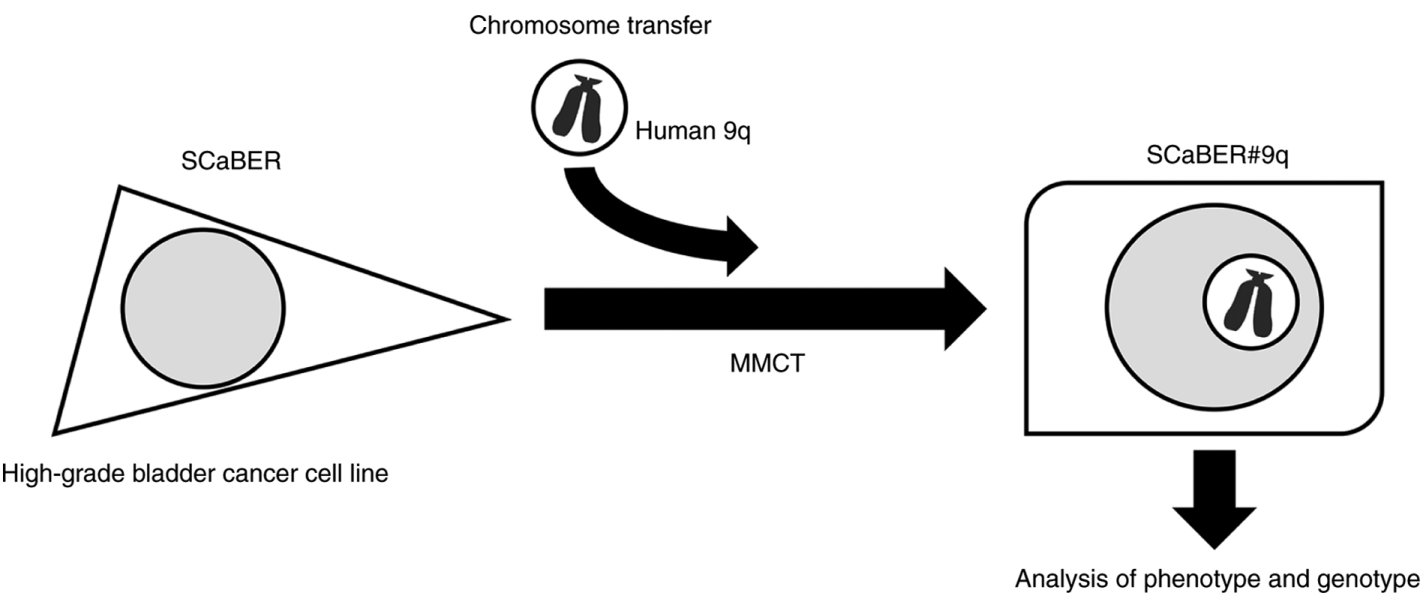

Figure 1. Long arm of human chromosome 9 was introduced into the bladder cancer cell line SCaBER via MMCT. MMCT, microcell-mediated chromosome transfer.

camera system (NIS-Elements Documentation, Ver.5.30; Nikon Corporation).

Western blotting. Western blotting was performed as previously described (17). Membranes were blotted with rabbit polyclonal antibodies against human PPAR $\gamma$ (cat. no. \#2430; 1:1,000; Cell Signaling Technology, Inc.), PTEN (cat.no.\#9188; 1:1,000; Cell Signaling Technology, Inc.) or $\alpha$-tubulin (cat. no. PM054-7; 1:5,000; Medical and Biological Laboratories Co., Ltd.) and anti-rabbit IgG horseradish peroxidase-linked antibody (cat. no. \#7074; 1:2,000; Cell Signaling Technology, Inc.), according to the manufacturer's instructions. Immunoreactive bands were visualized using an enhanced chemiluminescence detection system (cat. no. 32106; Pierce ${ }^{\mathrm{TM}}$ ECL Western Blotting Substrate; Thermo Fisher Scientific, Inc.). Protein bands on western blot films were quantified using ImageJ (ver.1.8.0; National Institutes of Health).

Survival analysis. The Cancer Genome Atlas (TCGA) (18) and National Cancer Institute Genomic Data Commons (19) public cancer genome bladder urothelial carcinoma (BLCA) dataset (accessed 20 June, 2021) was visualized and analyzed using UCSC Xena (xena.ucsc.edu). Overall survival curve was obtained using the Kaplan-Meier method with the median expression of each gene as the cutoff (PPARG: $<19.31 \mathrm{vs}$. $\geq 19.31$; FOXA1: $<18.80$ vs. $\geq 18.80 '$ GATA3: $<20.52$ vs. $\geq 20.52$ ), and differences in survival were evaluated with the log-rank test.

Statistical analysis. Data from triplicate experiments are presented as the mean \pm standard error of the mean. Data were analyzed using one-way ANOVA with post-hoc Tukey's honestly significant difference test. All statistical analysis was performed using SPSS Statistics software (version 24.0; IBM Corp.) $\mathrm{P}<0.05$ was considered to indicate a statistically significant difference.

\section{Results}

Analysis of mouse A9/human mono-chromosomal hybrids. The strategy for investigation of tumor suppressor effect of human chromosome 9 in $\mathrm{BCa}$ is shown in Fig. 1. We previously generated a library of A9 hybrid cells, each containing one of the human chromosomes (except Y) (20). To confirm the status of human chromosome 9 in A9(neo9) cells, PCR analysis using 21 STS markers located on human chromosome 9 was performed (Fig. 2). PCR analysis showed deletion of the short arm loci of human chromosome 9 (\#9delp12-pter) in A9(neo9) cells (Fig. 2). FISH analysis was performed in A9(neo9) cells using neo-plasmid probe. The pSV2neo probe for \#9delp12-pter was randomly integrated into two regions, \#9p12 and \#9q34.3 (Fig. 3A). Additionally, the long arm of human chromosome 9, was independently retained in mouse A9 cells.

Introduction of human chromosome $9 q$ into SCABER cells. Human chromosome $9 \mathrm{q}$ was transferred into SCaBER cells using MMCT. Microcell hybrid cells were isolated via three successive chromosome transfer experiments and analyzed to confirm the presence of transferred \#9delp12-pter tagged with pSV2neo by FISH. Transferred \#9delp12-pter was stably retained in the microcell hybrid clone (SCaBER\#9q; Fig. 3B). Microcell hybrids with introduced chromosome 4 (SCaBER\#4) were used as a control. The presence of transferred chromosome 4 in SCaBER\#4 was confirmed by FISH analysis using a PR11-q4C13 BAC probe containing the 4q22.1 genomic DNA region. The parental SCaBER cells had two copies of chromosome 4, whereas SCaBER\#4 microcell hybrid clones had three copies of chromosome 4; this confirmed the presence of the transferred chromosome (Fig. 3C and D).

The morphological features of microcell hybrid clones generated via introduction of a human chromosome were microscopically examined. SCaBER\#9q cells were flatter and larger than parental SCaBER and SCaBER\#4 cells (Fig. 3E). Thus, human chromosome $9 \mathrm{q}$ may have carried genes that regulated this transformed phenotype in SCaBER cells.

Effect of chromosome $9 q$ introduction on cell proliferation and migration ability. The proliferation rate of microcell hybrid clones was examined to determine the effects of chromosome transfer on cell proliferation. SCaBER\#9q cells exhibited significantly decreased proliferation compared with control SCaBER\#4 and parental cells at days 3-5 (Fig. 4A). 

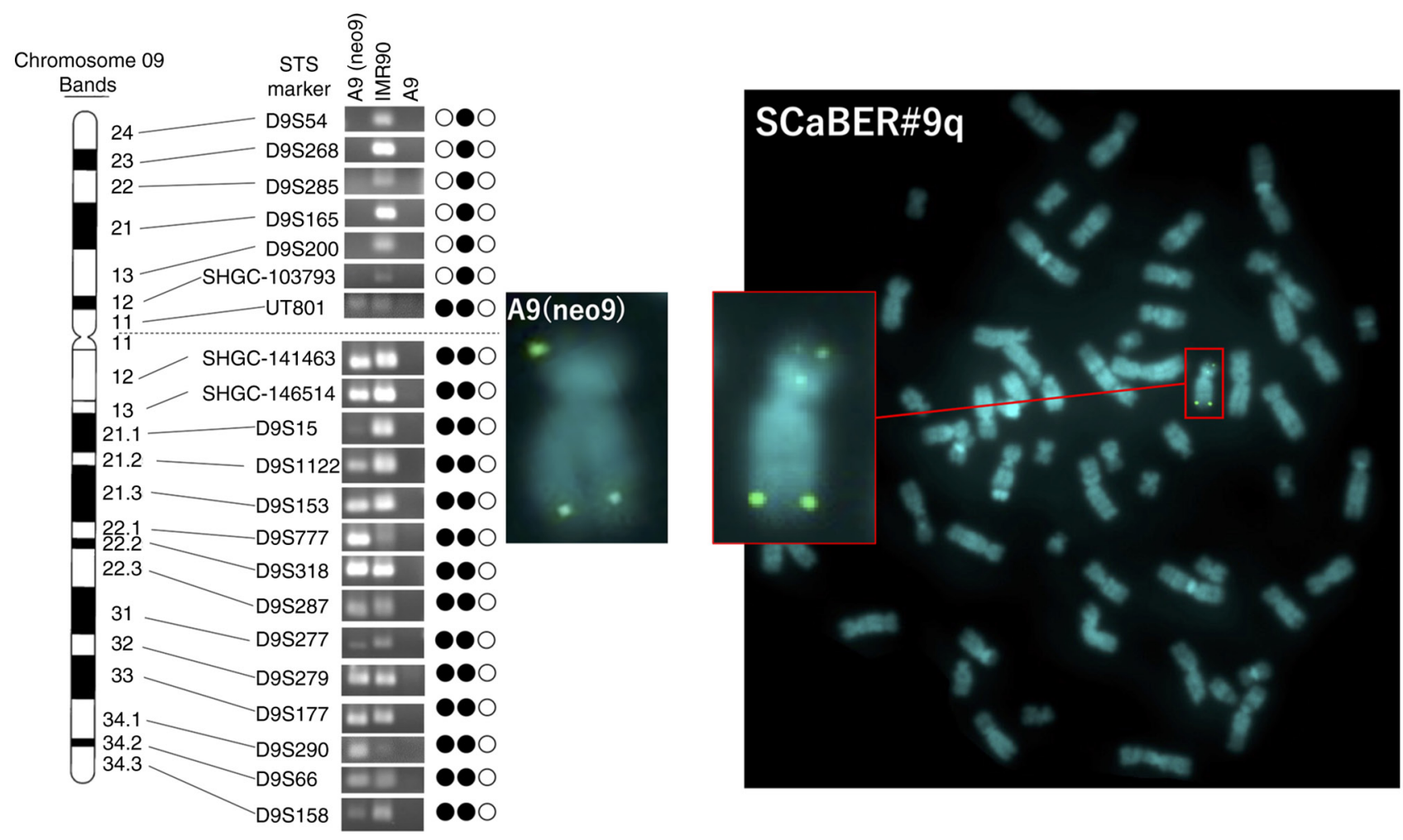

Figure 2. Presence or absence of the region 9p24.2-9q34.3 on human chromosome 9q contained in mouse A9(neo9) was verified by PCR. PCR analysis showing deletion of short arm loci of human chromosome 9 (\#9delp12-pter) in mouse A9(neo9) cells. IMR90, a normal human fibroblast cell line, was used as a positive control. STS, sequence-tagged site.

To evaluate the role of chromosome $9 \mathrm{q}$ in regulation of malignant potential of basal $\mathrm{BCa}$, wound healing assay was performed using SCaBER microcell hybrid clones. Compared with parental SCaBER and SCaBER\#4 cells, SCaBER\#9q cells showed decreased mobility (Fig. 4B and C). This indicated that tumor suppressor genes involved in cell proliferation and migration in SCaBER cells were present on $9 \mathrm{q}$.

Expression profile analysis of luminal markers. The luminal subtype of $\mathrm{BCa}$ has a lower proliferative and migratory potential than the basal subtype and is less malignant (8). GATA3, FOXA1, and PPAR $\gamma$ are specifically upregulated in the luminal subtype (as previously determined by RNA sequencing analysis) (21). Furthermore, overexpression of GATA3 and FOXA1, which are tumor suppressive, is accompanied by activation of PPAR $\gamma$ in transformation of basal into luminal BCa cells (22-26). Additionally, $\mathrm{LOH}$ on the long arm of chromosome 9 is commonly observed in premalignant lesions of bladder carcinogenesis, suggesting that chromosome $9 q$ encodes tumor suppressor genes that serve a key role in development and progression of $\mathrm{BCa}$. The expression levels of luminal markers (FOXA1, GATA3 and PPARG) was examined; compared with SCaBER cells, SCaBER\#9q cells exhibited a 2.4-, 1.9- and 5.2-fold increase in the expression of the aforementioned luminal markers (Fig. 5A-C).

A heatmap of differential molecular subtypes was used to evaluate the relative expression of luminal markers (Fig. 5D). The relative expression level of luminal markers was high in RT4 cells (typical luminal subtype), whereas SCaBER (basal) and T24 cells (non-type) exhibited low expression levels (27).
Only expression of PPARG was higher in SCaBER\#9q cells than in parental, SCaBER\#4 and RT4 cells (Fig. 5D). The expression profiles of three luminal marker genes in $\mathrm{BCa}$ was further investigated using BLCA dataset. Higher expression of all luminal marker genes was associated with improved survival in patients with BCa (Fig. 6). These results suggested that tumor suppressor genes on $9 q$ may serve an important role in determining the molecular subtype of $\mathrm{BCa}$, which is associated with development of malignancy.

Analysis of protein expression of luminal markers. Western blotting was performed to confirm that expression of luminal markers (GATA3, FOXA1. and PPARG) was also increased at the protein level. Only PPAR $\gamma$ was significantly increased in SCaBER\#9q cells (3.0-4.4-fold) compared with parental cells (Figs. 7A and B and S1). PPAR $\gamma$ inhibits proliferation, metastasis and invasion of cancer by induction of PTEN expression (28). The expression levels of PTEN were also increased in SCaBER\#9q cells (Fig. 7A and B). This suggested that chromosome $9 \mathrm{q}$ carried genes that regulate luminal marker of $\mathrm{BCa}$.

\section{Discussion}

BCa drug treatment has been based on cisplatin-based chemotherapy for 30 years but the development of immunotherapy (pembrolizumab) using immune checkpoint inhibitors has presented a change for BCa treatment. However, pembrolizumab only has a $21.1 \%$ response and $7.0 \%$ complete response rate (29). Therefore, there is a need for precision medicine, 

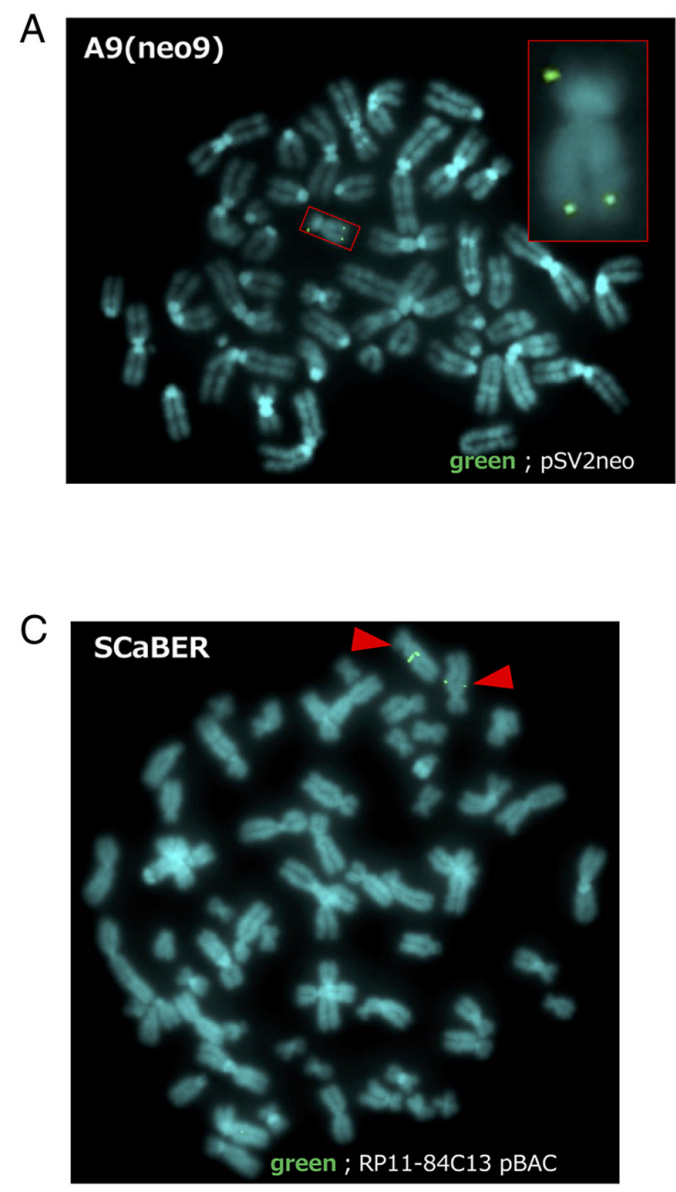

\section{$\mathrm{E}$}
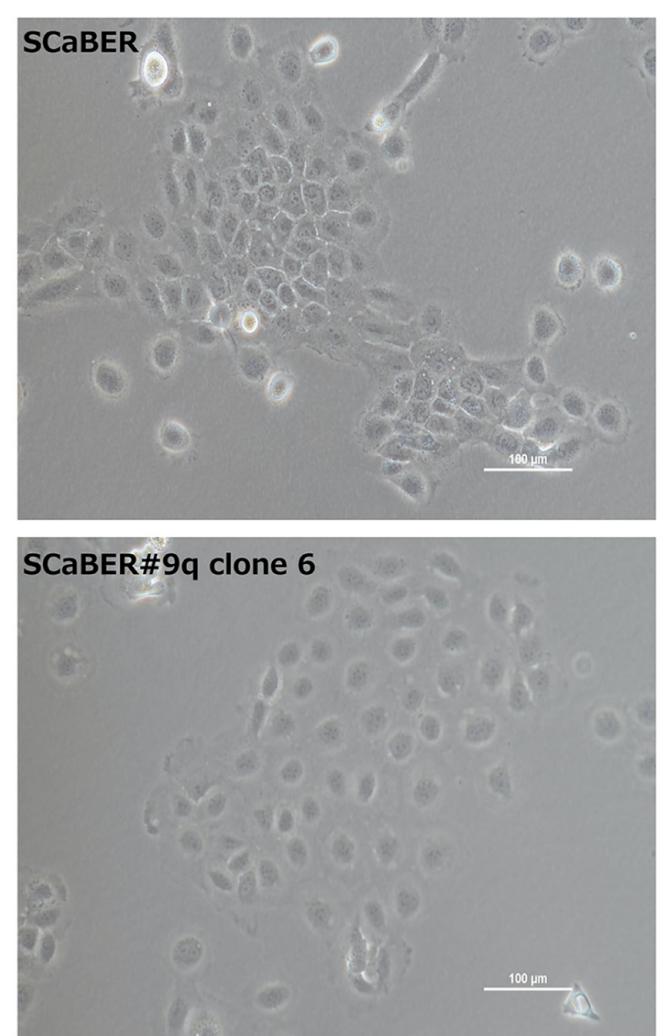

$\mathrm{B}$
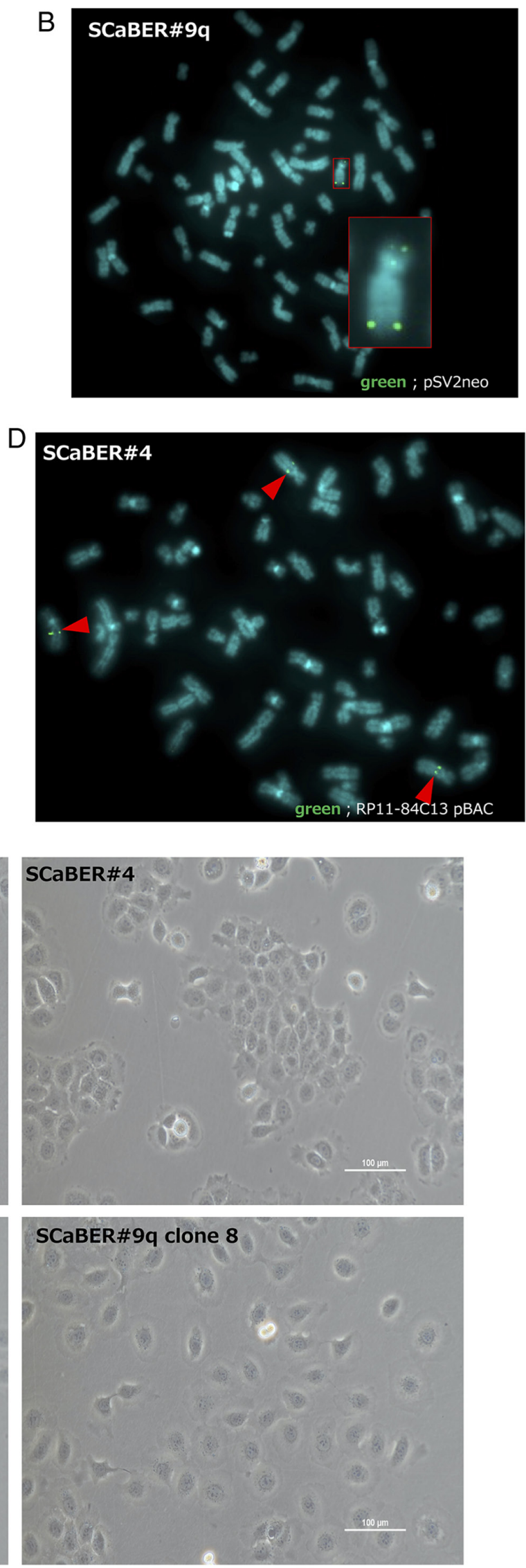

Figure 3. Chromosomal FISH identified successful transference of chromosome 9q in metaphase spreads and morphological change. (A) Human chromosome 9 in A9(neo9) cells and (B) transfer of 9q to SCaBER cells by MMCT from mouse A9(neo9) cells were confirmed by FISH (probeDNA: pSV2neo). (C) Three copies of chromosome 4 in SCaBER cells and (D) transfer of human chromosome 4 (Chr.4) to SCaBER by MMCT from mouse A9(neo4) cells were confirmed by FISH (probeDNA: RP11-84C13 pBAC) and arrowheads indicate chromosome 4. (E) Compared with SCaBER (parental strain), SCaBER\#9q showed a decrease in nuclear-cytoplasmic ratio and altered cell morphology. Magnification, x200. FISH, fluorescent in situ hybridization; MMCT, microcell-mediated chromosome transfer. 
A

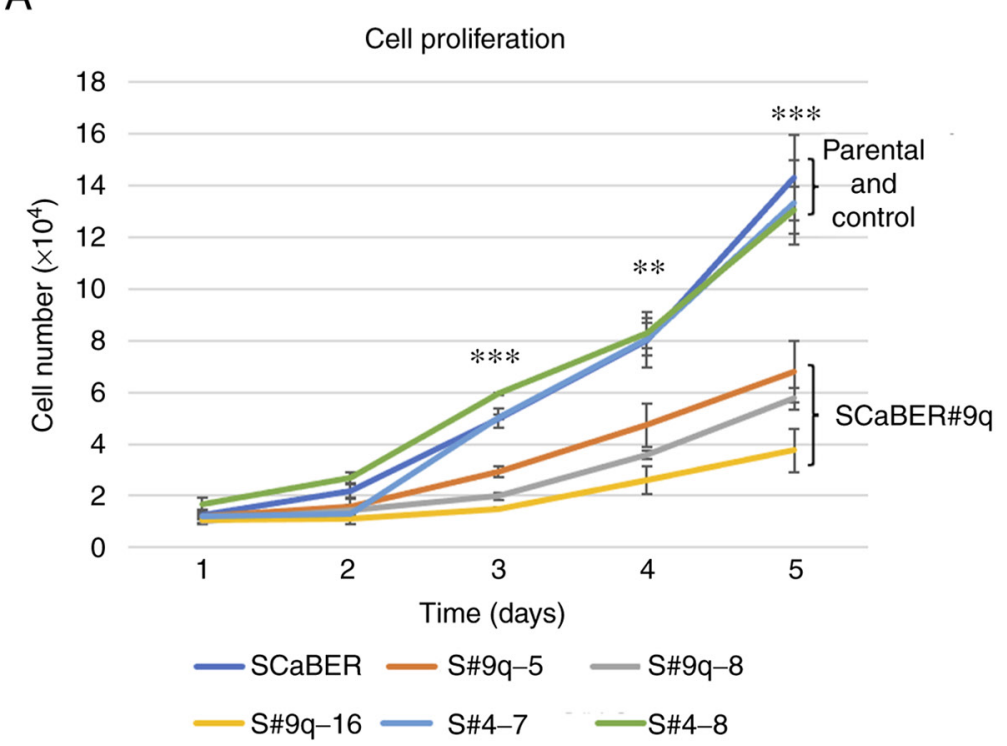

C

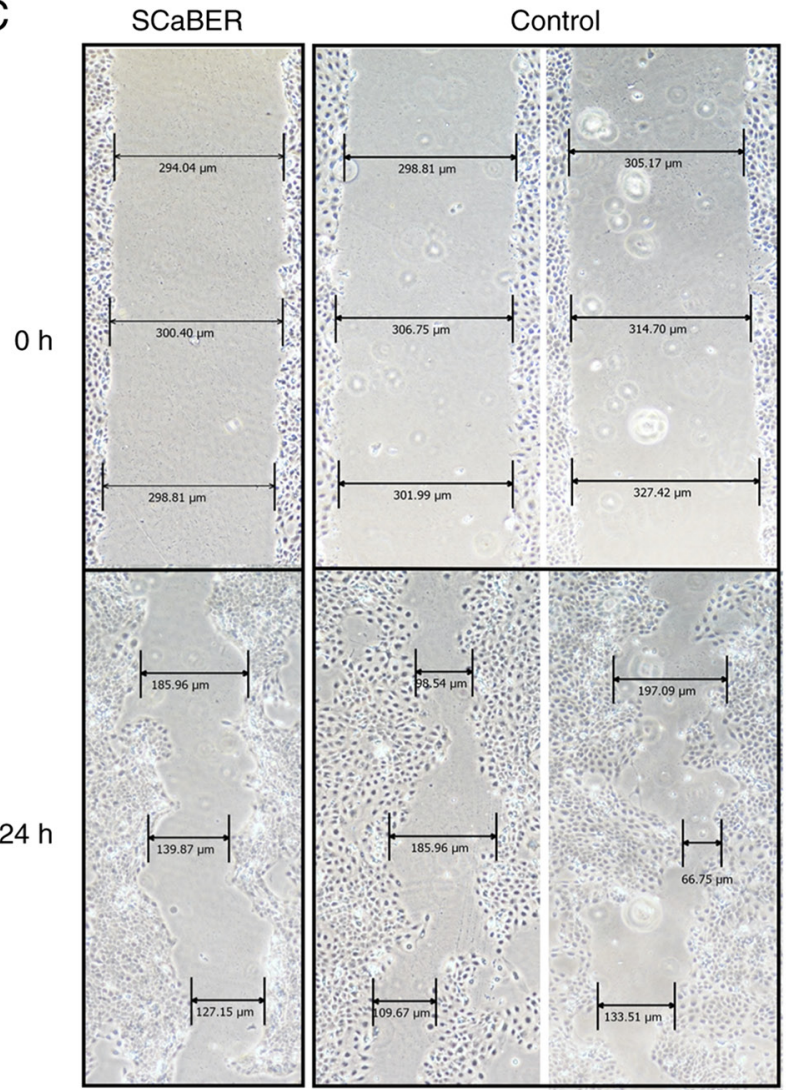

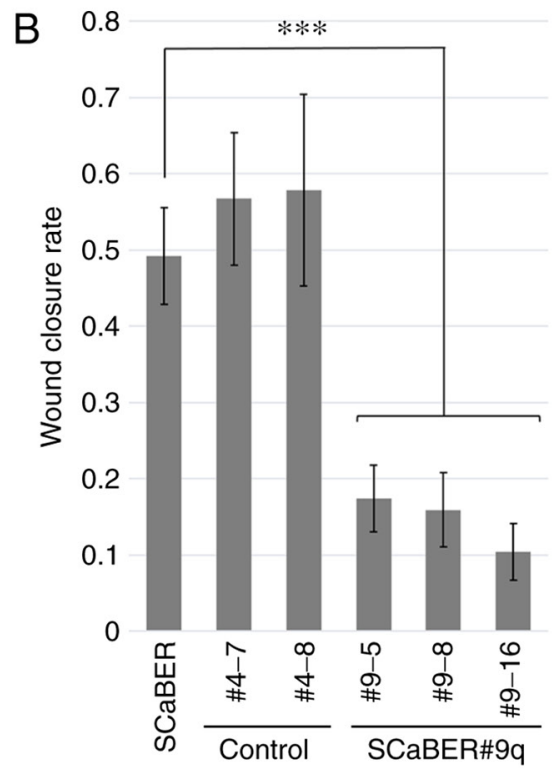

B
SCaBER\#9q

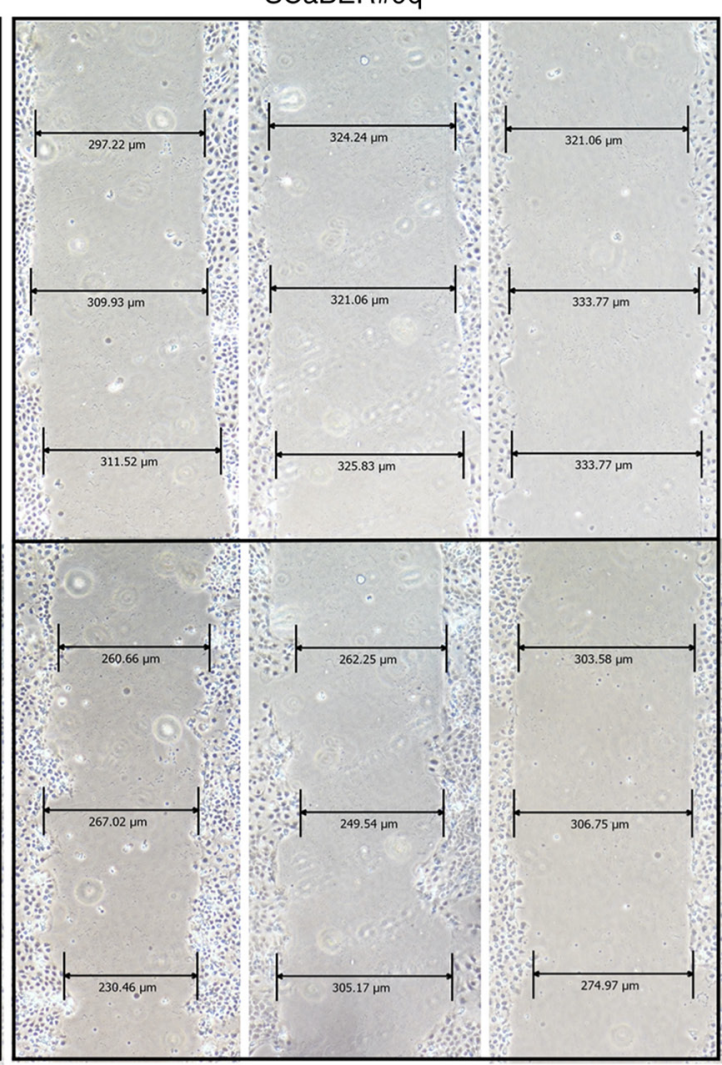

Figure 4. 9q-transfected clones showed decreased cell proliferation and migration ability. (A) Cell proliferation assay showed a significantly decreased proliferation rate in human bladder cancer cells transfected with the long arm of chromosome 9 (SCaBER\#9q) compared with control SCaBER\#4 and parental cells. ${ }^{* *} \mathrm{P}<0.01,{ }^{* * * *} \mathrm{P}<0.001$. (B) Wound closure rate showed a significant decrease in migration ability of SCaBER\#9q. Data are presented as the mean \pm SEM of triplicate experiments. ${ }^{* * *} \mathrm{P}<0.001$. (C) The cells scratched by $200-\mu 1$ pipette tips were placed in serum-free medium (DMEM) and measured and evaluated using a digital camera system (NIS-Elements Documentation, Ver.5.30; Nikon Corporation) at 0 and 24 h. Magnification, x80.

identification of biomarkers that can be used as predictors of therapeutic efficacy and development of novel therapies. Greater understanding of the molecular mechanisms underlying the development and progression of $\mathrm{BCa}$ is therefore key. Identification of novel tumor suppressor genes involved in progression of $\mathrm{BCa}$ may clarify the mechanism of its development and lead to identification of new therapeutic targets. The present study showed that malignant phenotypes, such as cell proliferation and migration, are suppressed in the SCaBER human high-grade basal $\mathrm{BCa}$ cell line following introduction of the long arm of human chromosome 9, resulting in enhanced expression of the luminal marker PPAR $\gamma$. This suggested that chromosome $9 \mathrm{q}$ carried genes that directly or indirectly regulated the PPARG luminal gene in SCaBER cells. 
A

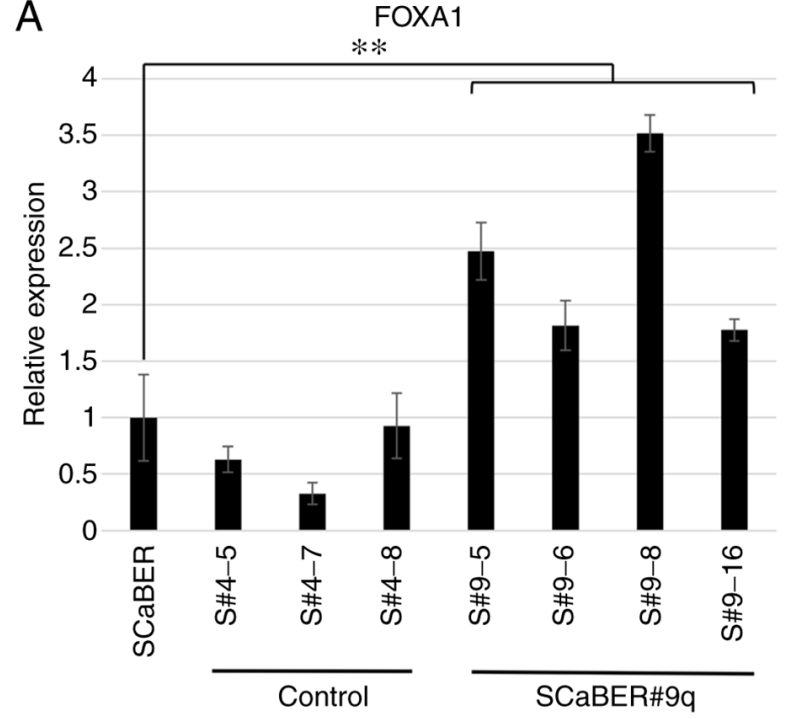

C

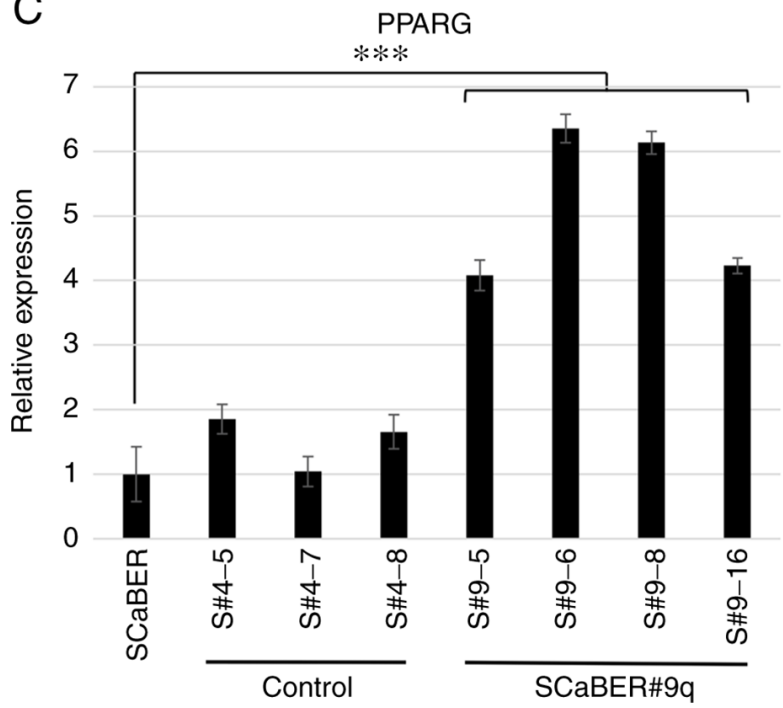

B

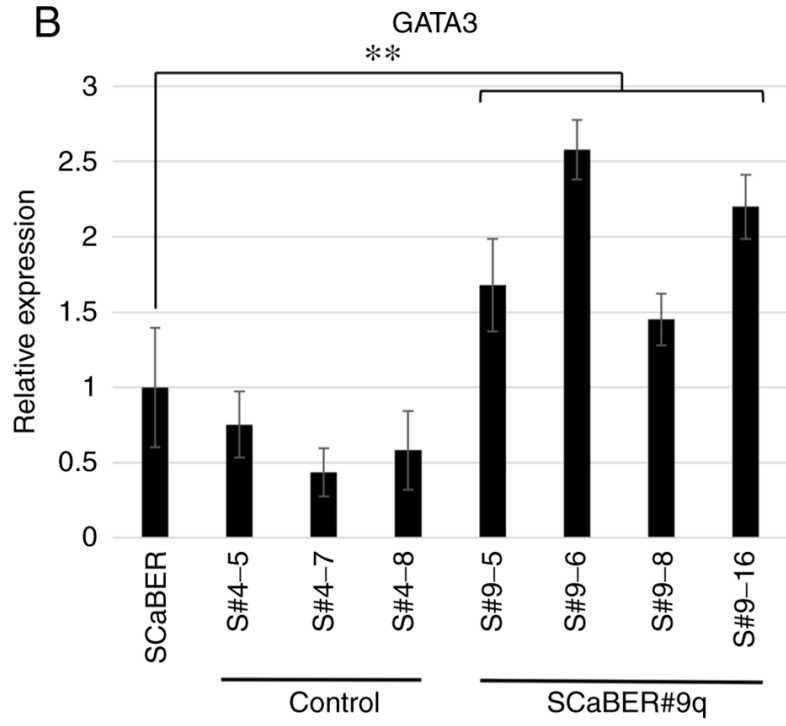

D

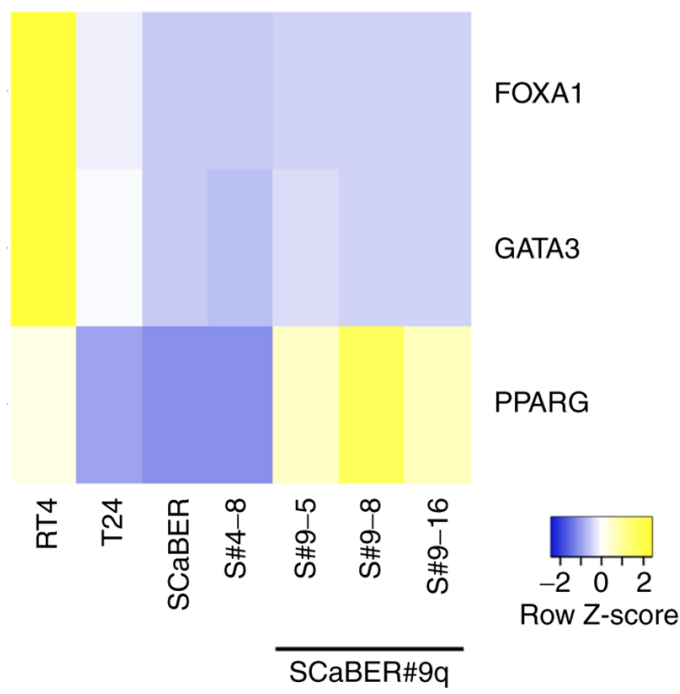

Figure 5. Reverse transcription-quantitative PCR of the luminal markers FOXA1, GATA3 and PPARG from cells transferred with 9q and control cells. Human bladder cancer cells transferred with long arm of chromosome 9 (SCaBER\#9q) showed 2.4-, 1.9-, and 5.2-fold increase in (A) FOXA1, (B) GATA3 and (C) PPARG expression, respectively, compared with SCaBER and SCaBER\#4 cells. Data are presented as the mean \pm SEM of triplicate experiments. ${ }^{* *} \mathrm{P}<0.01$, ${ }^{* * * *} \mathrm{P}<0.001$. (D) Heatmap of expression levels of FOXA1, GATA3 and PPARG compared with other cell lines (RT4, luminal; T24, non-type; 5637, basal). Gene expression levels were normalized against GAPDH mRNA using the $2^{-\Delta \Delta C a}$ method. FOXA1, forkhead box A1.
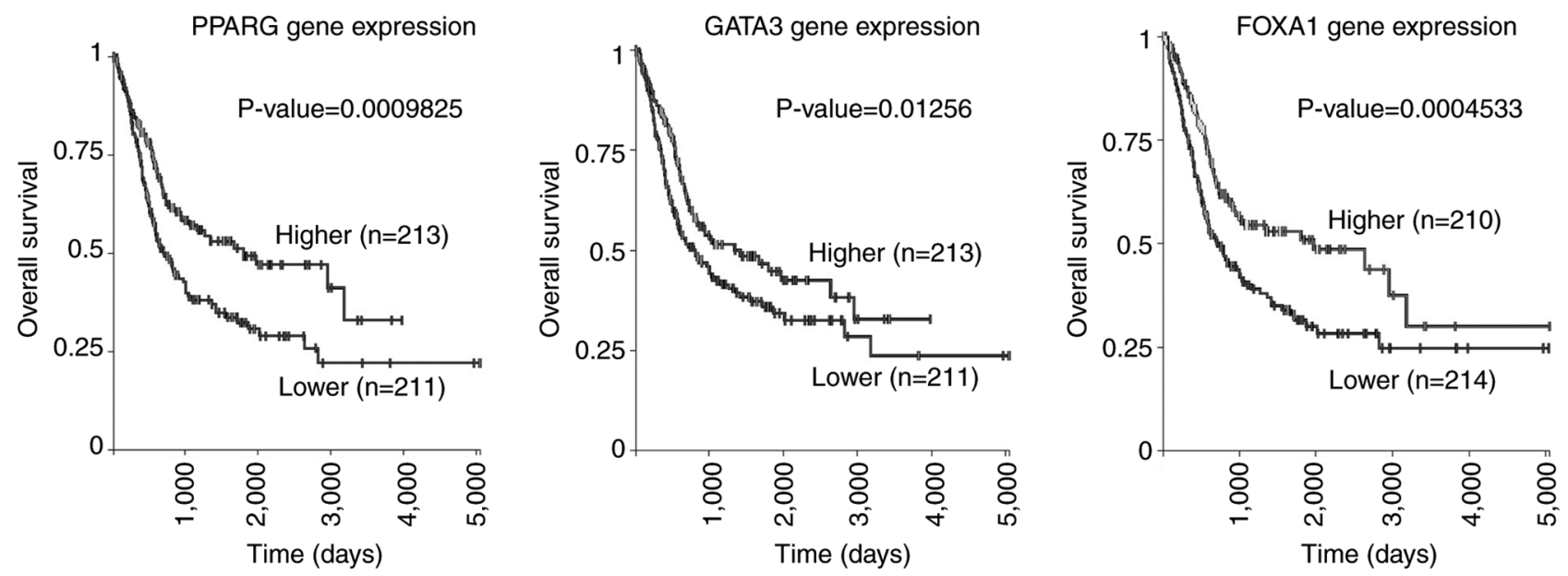

Figure 6. Expression profiles of three luminal marker genes in BCa was investigated using public datasets. Association between expression levels of PPARG, GATA3 and FOXA1 and overall survival from The Cancer Genome Atlas and the National Cancer Institute Genomic Data Commons database. 
A
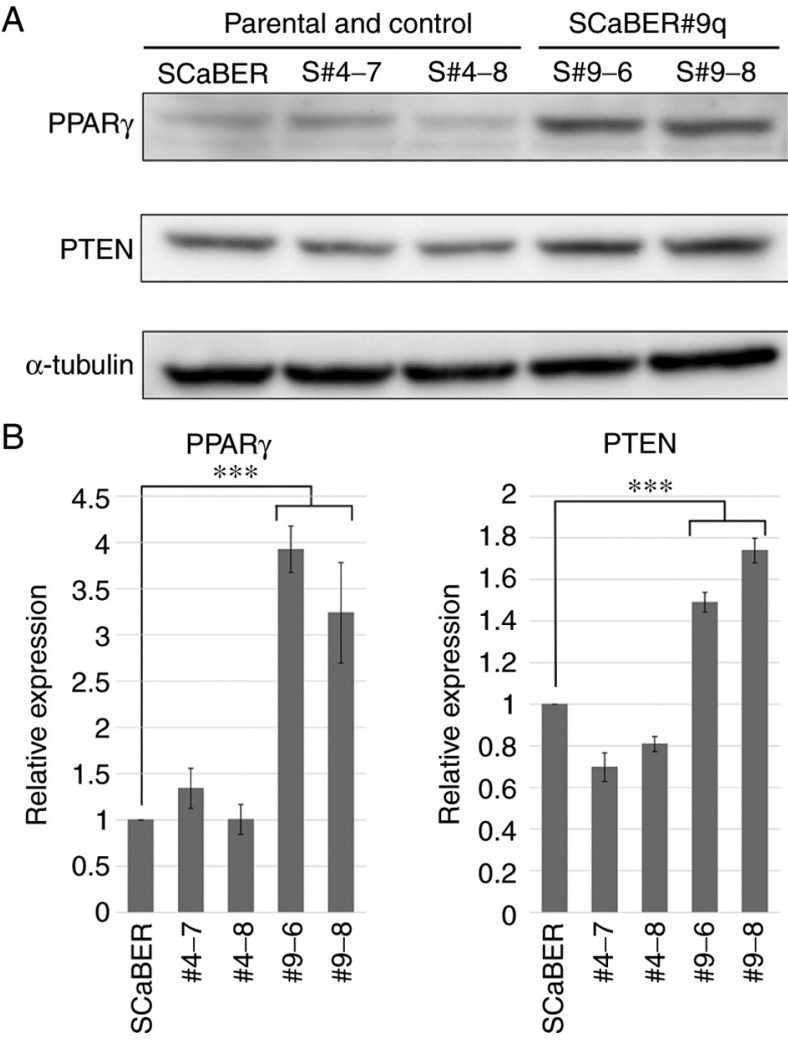

Figure 7. Western blotting of PPARG and PTEN from cells transfected with 9q and control cells. (A) Human bladder cancer cells transfected with long arm of chromosome 9 (SCaBER\#9q) cells showed increased PPARG and PTEN expression compared with SCaBER and SCaBER\#4 cells. (B) Relative expression was calculated by normalizing against $\alpha$-tubulin. Bars correspond to the mean $\pm \mathrm{SEM}$ of triplicate experiments. ${ }^{* * *} \mathrm{P}<0.001$.

(PPARG, FOXA1, GATA3 upregulation)

Luminal papillary pathway
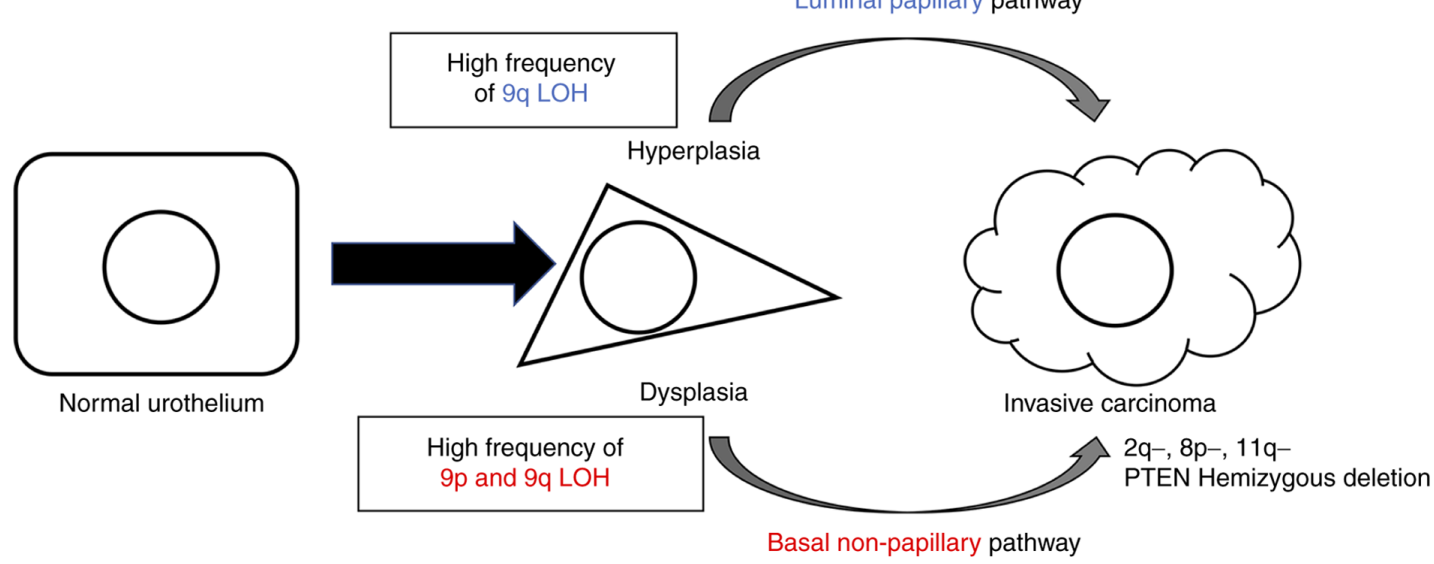

Figure 8. Schematic representation of carcinogenesis and progression of bladder cancer. High frequency of LOH in 9q is a common early event and deletion of 2q, 8p and 11q are late events in bladder cancer carcinogenesis. GATA3, FOXA1, and PPAR $\gamma$ are upregulated in the luminal pathway of bladder cancer progression. LOH, loss of heterozygosity; FOXA1, forkhead box A1.

TCGA, MD Anderson Cancer Center and other research groups have reported that urothelial carcinoma can be classified into basal and luminal subtypes by gene expression profiling $(30,31)$. Based on this classification and pathological characteristics, two pathways of carcinogenesis have been proposed: Papillary/luminal pathway, which leads to hyperplasia, papillary non-invasive and invasive carcinoma, and the non-papillary/basal pathway, which leads to flat dysplasia, carcinoma in situ and non-papillary invasive carcinoma
(Fig. 8) (8). GATA3, FOXA1, and PPAR $\gamma$ are upregulated in the luminal pathway and overexpression of GATA3 and FOXA1 and PPAR $\gamma$ activation drive transdifferentiation from the basal to luminal phenotype (23). In the present study, transcription levels of PPARG, FOXA1 and GATA3 were upregulated in SCaBER\#9q cells compared with parental and SCaBER\#4 cells. However at the protein level, only PPAR $\gamma$ was upregulated in SCaBER\#9q cells. Translation is affected by various regulatory factors, such as the cap-binding protein 
eIF4E and microRNAs $(32,33)$. Therefore, the discrepancy between mRNA and protein expression of luminal genes in SCaBER\#9q cells may be because of specific regulatory factors of translation.

PPARs, which are members of the nuclear receptor superfamily, can be divided into three subtypes: PPAR $\alpha, \beta$ and $\gamma$ (34). Previous studies have shown that PPAR $\gamma$ serves a key role in occurrence and progression of $\mathrm{BCa}$ via regulation of proliferation, apoptosis, metastasis, reactive oxygen species and lipid metabolism (26,35-38). High expression of PPAR $\gamma$ indicates better prognosis for patients with more differentiated, non-invasive tumors with low proliferative potential (39).

Aberration of chromosome 9, including deletions and $\mathrm{LOH}$, is frequently observed in both non-muscle and muscle invasive $\mathrm{BCa}(>50 \%)$. In particular, p16, a tumor suppressor gene located on chromosome $9 \mathrm{p}$, plays a key role in the progression of non-muscle invasive $\mathrm{BCa}(40-44)$ but the functional role of novel suppressor genes on $9 \mathrm{q}$ in $\mathrm{BCa}$ remains unclear. In the present study, expression levels of PPAR $\gamma$ and PTEN were significantly increased by introduction of $9 q$ to basal BCa cells (SCaBER), suggesting a transformation from poorly differentiated to more highly differentiated, low-grade $\mathrm{BCa}$. The proliferative and migratory ability of SCaBER\#9q cells also decreased. These results support a previous study showing that PPAR $\gamma$ inhibits proliferation, metastasis and invasion of cancer by inducing PTEN expression (28). However, there are conflicting reports on the association between PPAR $\gamma$ and PTEN in BCa $(17,45)$. The present findings may provide insight into PTEN regulatory pathways.

In conclusion, the present study provided evidence that the long arm of human chromosome 9 contained genes that regulate PPAR $\gamma$. We previously identified paired-like homeodomain 1 as a novel tumor suppressor gene on human chromosome 5 that regulates telomerase activity chromosome transfer and gene expression profiling analysis (46). Future identification and characterization of putative PPAR $\gamma$ regulatory genes on $9 q$ should facilitate understanding of the molecular mechanisms involved in the development of $\mathrm{BCa}$.

\section{Acknowledgements}

Not applicable.

\section{Funding}

The present study was supported by Japan Society for the Promotion of Science KAKENHI (grant no. 21K09422).

\section{Availability of data and materials}

The datasets used and analyzed during the current study are available from the corresponding author upon reasonable request.

\section{Authors' contributions}

TYa, TO and HK designed the experiments and analyzed the data. TYa, TO and RS performed experiments. TO and HK wrote the manuscript. TYu, NY, HI, SM, KH and MH analyzed data. TO and HK confirm the authenticity of all the raw data.
HK and AT conceived and supervised the project. All authors revised and edited the manuscript. All authors have read and approved the final version of the manuscript.

\section{Ethics approval and consent to participate}

Not applicable.

\section{Patient consent for publication}

Not applicable.

\section{Competing interests}

The authors declare that they have no competing interests.

\section{References}

1. Siegel RL, Miller KD and Jemal A: Cancer statistics, 2016. CA Cancer J Clin 66: 7-30, 2016.

2. Kakizoe T, Tobisu K, Takai K, Tanaka Y, Kishi K and Teshima S: Relationship between papillary and nodular transitional cell carcinoma in the human urinary bladder. Cancer Res 48: 2299-2303, 1988.

3. Luis NM, López-Knowles E and Real FX: Molecular biology of bladder cancer. Clin Transl Oncol 9: 5-12, 2007.

4. Fadl-Elmula I: Chromosomal changes in uroepithelial carcinomas. Cell Chromosome 4: 1, 2005.

5. Lindgren D, Sjödahl G, Lauss M, Staaf J, Chebil G, Lövgren K, Gudjonsson S, Liedberg F, Patschan O, Månsson W, et al: Integrated genomic and gene expression profiling identifies two major genomic circuits in urothelial carcinoma. PLoS One 7: e38863, 2012.

6. Nishiyama N, Arai E, Nagashio R, Fujimoto H, Hosoda F, Shibata T, Tsukamoto T, Yokoi S, Imoto I, Inazawa J and Kanai Y: Copy number alterations in urothelial carcinomas: Their clinicopathological significance and correlation with DNA methylation alterations. Carcinogenesis 32: 462-469, 2011.

7. Hurst CD, Platt FM, Taylor CF and Knowles MA: Novel tumor subgroups of urothelial carcinoma of the bladder defined by integrated genomic analysis. Clin Cancer Res 18: 5865-5877, 2012.

8. Czerniak B, Dinney C and McConkey D: Origins of bladder cancer. Annu Rev Pathol 11: 149-174, 2016.

9. Hartmann A, Schlake G, Zaak D, Hungerhuber E, Hofstetter A, Hofstaedter F and Knuechel R: Occurrence of chromosome 9 and 553 alterations in multifocal dysplasia and carcinoma in situ of human urinary bladder. Cancer Res 62: 809-818, 2002.

10. Hopman AH, Moesker O, Smeets AW, Pauwels RP, Vooijs GP and Ramaekers FC: Numerical chromosome 1, 7, 9, and 11 aberrations in bladder cancer detected by in situ hybridization. Cancer Res 51: 644-651, 1991.

11. Platt FM, Hurst CD, Taylor CF, Gregory WM, Harnden P and Knowles MA: Spectrum of phosphatidylinositol 3-kinase pathway gene alterations in bladder cancer. Clin Cancer Res 15: 6008-6017, 2009.

12. Sjödahl G, Lauss M, Gudjonsson S, Liedberg F, Halldén C, Chebil G, Månsson W, Höglund M and Lindgren D: A systematic study of gene mutations in urothelial carcinoma; inactivating mutations in TSC2 and PIK3R1. PLoS One 6: e18583, 2011.

13. Rampias T, Vgenopoulou P, Avgeris M, Polyzos A, Stravodimos K, Valavanis C, Scorilas A and Klinakis A: A new tumor suppressor role for the Notch pathway in bladder cancer. Nat Med 20: 1199-1205, 2014.

14. Kugoh H, Ohira T and Oshimura M: Studies of tumor suppressor genes via chromosome engineering. Cancers (Basel) 8: 4, 2015.

15. Livak KJ and Schmittgen TD: Analysis of relative gene expression data using real-time quantitative PCR and the 2(-Delta Delta C(T)) method. Methods 25: 402-408, 2001.

16. Uejima H, Mitsuya K, Kugoh H, Horikawa I and Oshimura M: Normal human chromosome 2 induces cellular senescence in the human cervical carcinoma cell line SiHa. Genes Chromosomes Cancer 14: 120-127, 1995.

17. Liu J, Zhang Y, Yu C, Zhang P, Gu S, Wang G, Xiao H and Li S: Bergenin inhibits bladder cancer progression via activating the PPAR $\gamma /$ PTEN/Akt signal pathway. Drug Dev Res 82: 278-286, 2021.

18. Chin L, Hahn WC, Getz G and Meyerson M: Making sense of cancer genomic data. Genes Dev 25: 534-555, 2011. 
19. Grossman RL, Heath AP, Ferretti V, Varmus HE, Lowy DR, Kibbe WA and Staudt LM: Toward a shared vision for cancer genomic data. N Engl J Med 375: 1109-1112, 2016.

20. Kugoh H, Mitsuya K, Meguro M, Shigenami K, Schulz TC and Oshimura M: Mouse A9 cells containing single human chromosomes for analysis of genomic imprinting. DNA Res 6: 165-172, 1999.

21. Eriksson P, Aine M, Veerla S, Liedberg F, Sjödahl G and Höglund M: Molecular subtypes of urothelial carcinoma are defined by specific gene regulatory systems. BMC Med Genomics 8: 25, 2015.

22. Hustler A, Eardley I, Hinley J, Pearson J, Wezel F, Radvanyi F, Baker SC and Southgate J: Differential transcription factor expression by human epithelial cells of buccal and urothelial derivation. Exp Cell Res 369: 284-294, 2018

23. Warrick JI, Walter V, Yamashita H, Chung E, Shuman L, Amponsa VO, Zheng Z, Chan W, Whitcomb TL, Yue F, et al: FOXA1, GATA3 and PPAR $\gamma$ cooperate to drive luminal subtype in bladder cancer: A molecular analysis of established human cell lines. Sci Rep 6: 38531, 2016.

24. Osei-Amponsa V, Buckwalter JM, Shuman L, Zheng Z, Yamashita H, Walter V, Wildermuth T, Ellis-Mohl J, Liu C, Warrick JI, et al: Hypermethylation of FOXA1 and allelic loss of PTEN drive squamous differentiation and promote heterogeneity in bladder cancer. Oncogene 39: 1302-1317, 2020.

25. Li Y, Ishiguro $\mathrm{H}$, Kawahara $\mathrm{T}$, Kashiwagi E, Izumi $\mathrm{K}$ and Miyamoto H: Loss of GATA3 in bladder cancer promotes cell migration and invasion. Cancer Biol Ther 15: 428-435, 2014.

26. Cheng S, Qian K, Wang Y, Wang G, Liu X, Xiao Y and Wang X PPAR $\gamma$ inhibition regulates the cell cycle, proliferation and motility of bladder cancer cells. J Cell Mol Med 23: 3724-3736, 2019.

27. Hau AM, Nakasaki M, Nakashima K, Krish G and Hansel DE: Differential mTOR pathway profiles in bladder cancer cell line subtypes to predict sensitivity to mTOR inhibition. Urol Oncol 35: 593-599, 2017.

28. Lin MS, Huang JX, Chen WC, Zhang BF, Fang J, Zhou Q, $\mathrm{Hu} \mathrm{Y}$ and Gao HJ: Expression of PPAR $\gamma$ and PTEN in human colorectal cancer: An immunohistochemical study using tissue microarray methodology. Oncol Lett 2: 1219-1224, 2011.

29. Bellmunt J, de Wit R, Vaughn DJ, Fradet Y, Lee JL, Fong L, Vogelzang NJ, Climent MA, Petrylak DP, Choueiri TK, et al: Pembrolizumab as second-line therapy for advanced urothelial carcinoma. N Engl J Med 376: 1015-1026, 2017.

30. Choi W, Czerniak B, Ochoa A, Su X, Siefker-Radtke A, Dinney C and McConkey DJ: Intrinsic basal and luminal subtypes of muscle-invasive bladder cancer. Nat Rev Urol 11: 400-410, 2014

31. Robertson AG, Kim J, Al-Ahmadie H, Bellmunt J, Guo G, Cherniack AD, Hinoue T, Laird PW, Hoadley KA, Akbani R, et al: Comprehensive molecular characterization of muscle-invasive bladder cancer. Cell 171: 540-556.e25, 2017.

32. Sonenberg N and Hinnebusch AG: New modes of translational control in development, behavior, and disease. Mol Cell 28: 721-729, 2007.

33. Zhou Y, Liang H, Liao Z, Wang Y, Hu X, Chen X, Xu L and $\mathrm{Hu}$ Z: miR-203 enhances let-7 biogenesis by targeting LIN28B to suppress tumor growth in lung cancer. Sci Rep 7: 42680, 2017.
34. Lemberger T, Braissant O, Juge-Aubry C, Keller H, Saladin R, Staels B, Auwerx J, Burger AG, Meier CA and Wahli W: PPAR tissue distribution and interactions with other hormone-signaling pathways. Ann N Y Acad Sci 804: 231-251, 1996.

35. Cheng S, Wang G, Wang Y, Cai L, Qian K, Ju L, Liu X, Xiao Y and Wang X: Fatty acid oxidation inhibitor etomoxir suppresses tumor progression and induces cell cycle arrest via PPAR $\gamma$-mediated pathway in bladder cancer. Clin Sci (Lond) 133: $1745-1758,2019$

36. Cao R, Wang G, Qian K, Chen L, Ju L, Qian G, Wu CL, Dan HC, Jiang $\mathrm{W}, \mathrm{Wu} \mathrm{M}$, et al: TM4SF1 regulates apoptosis, cell cycle and ROS metabolism via the PPAR $\gamma$-SIRT1 feedback loop in human bladder cancer cells. Cancer Lett 414: 278-293, 2018.

37. Cao R, Wang G, Qian K, Chen L, Qian G, Xie C, Dan HC, Jiang W, Wu M, Wu CL, et al: Silencing of HJURP induces dysregulation of cell cycle and ROS metabolism in bladder cancer cells via PPAR $\gamma$-SIRT1 feedback loop. J Cancer 8: 2282-2295, 2017.

38. Wang G, Cao R, Wang Y, Qian G, Dan HC, Jiang W, Ju L, Wu M, Xiao Y and Wang X: Simvastatin induces cell cycle arrest and inhibits proliferation of bladder cancer cells via PPAR $\gamma$ signalling pathway. Sci Rep 6: 35783, 2016.

39. Mylona E, Giannopoulou I, Diamantopoulou K, Bakarakos P, Nomikos A, Zervas A and Nakopoulou L: Peroxisome proliferator-activated receptor gamma expression in urothelial carcinomas of the bladder: Association with differentiation, proliferation and clinical outcome. Eur J Surg Oncol 35: 197-201, 2009.

40. Cairns P, Mao L, Merlo A, Lee DJ, Schwab D, Eby Y, Tokino K, van der Riet P, Blaugrund JE and Sidransky D: Rates of p16 (MTS1) mutations in primary tumors with 9p loss. Science 265: 415-417, 1994.

41. Williamson MP, Elder PA, Shaw ME, Devlin J and Knowles MA: p16 (CDKN2) is a major deletion target at 9p21 in bladder cancer. Hum Mol Genet 4: 1569-1577, 1995.

42. Ploussard G, Dubosq F, Soliman H, Verine J, Desgrandchamps F, De Thé $\mathrm{H}$ and Mongiat-Artus P: Prognostic value of loss of heterozygosity at chromosome $9 \mathrm{p}$ in non-muscle-invasive bladder cancer. Urology 76: 513.e13-e18, 2010.

43. Krüger S, Mahnken A, Kausch I and Feller AC: P16 immunoreactivity is an independent predictor of tumor progression in minimally invasive urothelial bladder carcinoma. Eur Urol 47: 463-467, 2005.

44. Bartoletti R, Cai T, Nesi G, Roberta Girardi L, Baroni G and Dal Canto M: Loss of P16 expression and chromosome 9p21 LOH in predicting outcome of patients affected by superficial bladder cancer. J Surg Res 143: 422-427, 2007.

45. Zhang Z, Xu H, Ji J, Shi X, Lyu J, Zhu Y, Yu H and Wang F: Heterogeneity of PTEN and PPAR- $\gamma$ in cancer and their prognostic application to bladder cancer. Exp Ther Med 18: 3177-3183, 2019.

46. Qi DL, Ohhira T, Fujisaki C, Inoue T, Ohta T, Osaki M, Ohshiro E, Seko T, Aoki S, Oshimura M and Kugoh H: Identification of PITX1 as a TERT suppressor gene located on human chromosome 5. Mol Cell Biol 31: 1624-1636, 2011.

This work is licensed under a Creative Commons Attribution-NonCommercial-NoDerivatives 4.0 International (CC BY-NC-ND 4.0) License. 